\title{
ISOLASI GEN SMTAB BAKTERI RESISTEN LOGAM BERAT Pb DARI LIMBAH CAIR AGAR
}

\author{
Generation Insulation smtAB Resistent Bacteria Pb Heavy Metal In Liquid Waste \\ Senja Ike Rismawati ${ }^{1}$ \\ ${ }^{1}$ Prodi Teknologi Hasil Perikanan Universitas Yudharta Pasuruan \\ Email: senjaiker@gmail.com
}

\begin{abstract}
ABSTRAK
Bakteri Indigen adalah bakteri asli yang memiliki kemampuan untuk mereduksi senyawa berbahaya termasuk logam berat $\mathrm{Pb}$. Bakteri indigen yang diisolasi dari limbah cair tepung agar diketehui memiliki kemampuan mereduksi logam berat $\mathrm{Pb}$ adalah Bacillus alvei, Bacillus pumilus dan Bacillus lichenformis. Kemampuan bakteri dalam mereduksi logam berat $\mathrm{Pb}$ disebabkan karena adanya gen resisten, yaitu gen $\operatorname{smt} A B$. Gen $s m t A B$ merupakan gen yang bekerja untuk menghasilkan protein pengikat logam berat yang disebut metallothionein. Setiap bakteri memiliki gen resisten logam berat yang berbeda, oleh karena itu penelitian ini bertujuan untuk mengetahui spesies bakteri yang memiliki gen $\operatorname{smt} A B$ pada bakteri yang diisolasi dari limbah cair agar. Jenis penelitian yang dilakukan adalah deskriptif kualitatif. Penelitian ini terdiri dari beberapa tahap, yaitu peremajaan isolat bakteri, kultur isolat bakteri, isolasi DNA dengan Presto ${ }^{\mathrm{TM}}$ Mini gDNA Bacteria Kit, Elektoforesis, amplifikasi gen $\operatorname{smtAB}$ dan konfirmasi sekuens dengan hasil sekuensing amplikon. Berdasarkan hasil amplifikasi, bakteri indigen limbah cair agar yang memiliki gen $\operatorname{smt} A B$ adalah bacillus alvei. Isolasi gen $\operatorname{smt} A B$ yang diakukan menghasilkan sekuen yang tidak spesifik dengan gen target.

Kata Kunci: Isolasi Gen smtAB, Bakteri Resisten Logam Berat Pb, Limbah Cair Agar
\end{abstract}

\section{ABSTRACT}

Indigenic bacteria are native bacteria that have the ability to reduce harmful compounds including $\mathrm{Pb}$ heavy metals. Indigenic bacteria isolated from flour liquid waste to be known to have the ability to reduce Pb heavy metals are Bacillus alvei, Bacillus pumilus and Bacillus lichenformis. The ability of bacteria to reduce Pb heavy metal is caused by the presence of resistant genes, namely the smtAB gene. The smtAB gene is a gene that works to produce heavy metal binding proteins called metallothionein. Each bacterium has a different heavy metal resistant gene, therefore this study aims to determine the bacterial species that have a common gene in bacteria isolated from agar liquid waste. The type of research conducted is qualitative descriptive. This study consisted of several stages, namely rejuvenation of bacterial

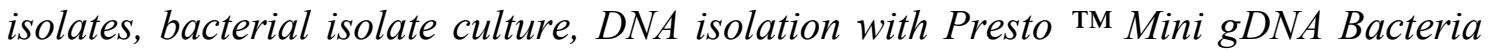
Kit, Electrophoresis, SMAB gene amplification and sequence confirmation with amplicon sequencing results. Based on the results of amplification, the liquid waste indigen bacteria so that the smtAB gene is bacillus alvei. The isolation of the SMT gene that was carried out produced a sequence that was not specific to the target gene.

Keywords: smtAB Gen Insulation, Pb Heavy Metal Resistant Bacteria, Agar Waste 


\section{PENDAHULUAN}

Pembangunan di bidang industri tidak jarang menimbulkan dampak negatif berupa limbah yang dihasilkan baik dalam bentuk padat, cair dan gas (Khasanah, 2009). Meningkatnya industrialisasi akan menyebabkan pula meningkatnya keluaran bahan kimia berbahaya ke lingkungan yang berasal dari limbah industri, terutama limbah yang mengandung logam berat (Gerdhart et al., 2008). Kontaminasi oleh logam berat menjadi perhatian serius karena dapat mencemari tanah maupun air tanah serta dapat menyebar ke daerah sekitarnya melalui air, angin dan dapat terakumulasi oleh tumbuhan (Knox et al., 2000). Logam berat juga tidak dapat didegradasi oleh tubuh dan bersifat racun pada mahluk hidup serta dapat terakumulasi dalam jangka waktu tertentu (Buhani, 2007).

Logam berat timbal $(\mathrm{Pb})$ dapat menyebabkan gangguan pada sistem saraf, hemotologic, hemetotoxic dan mempengaruhi kerja ginjal (Suhendrayatna, 2001). Pemaparan jangka panjang logam berat timbal $(\mathrm{Pb})$ pada manusia dapat menyebabkan anemia, kanker, mengganggu metabolisme vitamin D dan dapat kematian jika dalam darah manusia mengandung 70 $\mu \mathrm{g} / \mathrm{dl}$ (Fonte et al, 2007; Lam et al, 2007 dan Steenland et al, 2000). Untuk mengurangi efek negatif yang timbulkan oleh logam berat maka digunakan pendekatan bioteknologi remediasi atau bioremediasi.

Bioremediasi merupakan teknik untuk mengurangi atau memecah senyawa berbahaya di lingkungan dengan memanfaatkan mikroorganisme (Soleimani dan Jaberi, 2014) seperti jamur, ragi, dan bakteri (Chatterjee et al., 2012). Terdapat banyak jenis bakteri yang berpotensi untuk bioremediasi, salah satunya adalah bakteri indigen yang diisolasi dari limbah cair agar PT X. Isolat Bakteri indigen yang telah berhasil diisolasi dari limbah cair agar adalah Bacillus alvei, Bacillus pumilus dan Bacillus lichenformis

Bakteri mampu bertahan hidup di lingkungan yang terkontaminasi logam berat karena mempunyai gen resisten. Salah satu gen resisten adalah gen $\operatorname{smt} A B$ yang terlibat dalam produksi protein (metallothionein) yang dapat mengikat logam berat (Shimoda et al., 2003). Penelitian ini bertujuan untuk mengetahui spesies bakteri indigen dari limbah cair agar PT X yang memiliki gen $s m t A B$

\section{METODE}

Penelitian ini dilakukan di laboratorium mikrobiologi Universitas Negeri Malang dan laboratorium Genetika dan Biologi 
Molekuler Departemen Biologi Fakultas Sains dan Teknologi Universitas Islam Negeri Maulana Malik Ibrahim Malang. Peralatan yang digunakan antara lain waterbath shaker, autoclave, tabung eppendorf, Laminar Air Flow, tabung sentrifugasi, mikropipet, mikrotip, frezeer, vortex, mesin sentrifugasi, GD column, collection tube, inkubator, kertas parafilm, UV box, seperangkat alat elektroforesis merek BioRad, transiluminator mesin UV (gel Doc ) seri molekul BioRad gel Doc $\mathrm{TM}$ Image $\mathrm{Xr}$ sistem pencitraan dan perangkat lunak Quantity One.

Bahan yang diperlukan antara lain isolat bakteri indigen limbah cair agar yaitu Bacillus alvei, Bacillus pumilus dan Bacillus lichenformis, $\mathrm{ddH}_{2} \mathrm{O}$, proteinase K, buffer TE, bahan dari Presto ${ }^{\mathrm{TM}}$ Mini gDNA Bacteria Kit, dan gel agarose $1 \%$. agarosa gel, TBE (Tris Boric EDTA), $\mathrm{EtBr}$ (Ethidium bromide), pemuatan pewarna, air deionisasi, Master Mix PCR merek Promega (Taq polimerase, dNTPs, buffer PCR), primer smt1 (5' GAT CGA CGT TGC AGA GAC AG 3') dan smt2 (5' GAT CGA GGG CGT TTT GAT AA 3'), marker, DNA terisolasi (template), aquabidest, air suling, dan es batu.

\section{Peremajaan Bakteri}

Peremajaan bakteri dilakukan dengan mengambil isolat bakteri sebanyak 1 ose secara aseptik dan digoreskan pada media miring, kemudian isolat diinkubasi pada suhu $37^{\circ} \mathrm{C}$.

\section{Persiapan Kultur Bakteri}

Isolat bakteri Bacillus alvei, Bacillus pumilus dan Bacillus lichenformis dibiakkan dalam medium cair LB dan ditumbuhkan selama 24 jam pada $37^{\circ} \mathrm{C}$ diaduk pada kecepatan 150-175 rpm dalam water bath shaker. Setelah 24 jam pertumbuhan sel Setelah itu isolat bakteri siap untuk diisolasi DNAnya

\section{Isolasi Genom DNA}

Isolasi genom DNA bakteri Bacillus alvei, Bacillus pumilus dan Bacillus lichenformis dilakukan menggunakan kit isolasi DNA yaitu Presto mini gDNA Bacteria Kit. Tahapan isolasi DNA bakteri adalah sebagai berikut:

1. Persiapan sampel: Pindahkan sel bakteri (minimal $1 \times 10^{9}$ ) pada tube microcentrifuge $1.5 \mathrm{ml}$. Sentrifugasi selama 1 menit pada 14 - $16.000 \mathrm{rpm}$ kemudian buang supernatan. Tuang buffer Gram + (200 $\mu 1 /$ sampel $)$ pada tube sentrifugasi $15 \mathrm{ml}$. Tambah Lysozyme (4 mg/ml) pada buffer gram + (dalam tube sentrifugasi $15 \mathrm{ml}$ ) kemudian vortex untuk melarutkan Lysozyme secara keseluruhan. Tuang $200 \mu \mathrm{l}$ buffer Gram + (yang telah ditambah Lysozyme) pada sampel di 
tube mikrosentrifugasi $1.5 \mathrm{ml}$ kemudian resuspensi pelet dengan vortex atau pipet. Inkubasi pada $37^{\circ} \mathrm{C}$ selama 30 menit. Selama inkubasi, balik-balik tube secara berkala. Tambahkan $20 \mu \mathrm{l}$ Pro K (yang telah ditambah $\mathrm{ddH}_{2} \mathrm{O}$ ). Inkubasi pada $60^{\circ} \mathrm{C}$ minimal 10 menit. Selama inkubasi, balik-balik tube setiap 3 menit.

2. Lisis: Tambahkan $200 \mu \mathrm{l}$ buffer GB pada sampel dan campur dengan vortex selama 10 detik. Inkubasi pada $70^{\circ} \mathrm{C}$ minimal 10 menit untuk memastikan lysate sampel telah hilang. Selama inkubasi, balik-balik tube setiap 3 menit. Saat ini, panaskan terlebih dulu buffer elusi yang diperlukan $(200 \mu \mathrm{l}$ per sampel) pada $70^{\circ} \mathrm{C}$ (untuk tahap 5 DNA Elusi).

3. Pengikatan DNA: Tambahkan $200 \mu 1$ etanol absolut pada sampel dan campur segera dengan mengocok kuat-kuat. Jika presipitat muncul, hancurkan dengan pipet. Tempatkan kolom GD dalam tube koleksi $2 \mathrm{ml}$. Tuang campuran (termasuk presipitat tidak terlarut) pada kolom GD kemudian sentrifugasi pada $14-16.000$ selama 2 menit. Lepas tube koleksi yang mengandung cairan kemudian tempatkan kolom GD pada tube koleksi $2 \mathrm{ml}$ baru.
4. Pencucian: Tambahkan $400 \mu$ l buffer W1 pada kolom GD. Sentrifugasi pada 14 - 16.000 selama 30 detik kemudian buat cairan. Tempatkan kembali kolom GD pada tube koleksi $2 \mathrm{ml}$. Tambah $600 \mu \mathrm{l}$ wash buffer (telah ditambah etanol) pada kolom GD. Sentrifugasi pada 14 - 16.000 selama 30 detik lalu buang cairan. Tempatkan kembali kolom GD pada tube koleksi $2 \mathrm{ml}$. Sentrifugasi lagi selama 3 menit pada 14 - 16.000 untuk mengeringkan matriks kolom.

5. Elusi Volume elusi standar adalah 100 $\mu 1$. Jika sampel yang digunakan kurang, kurangi volume elusi (30-50 $\mu \mathrm{l})$ untuk meningkatkan konsentrasi DNA. Jika menginginkan hasil DNA lebih tinggi, ulangi tahap elusi untuk meningkatkan perolehan DNA dan volume total elusi sekitar $200 \mu$ l. Pindahkan kolom GD kering pada tube microcentrifuge 1.5 ml. Tambah $100 \mu l$ buffer TE ke tengah matriks kolom. Biarkan selama 3 menit supaya buffer TE diserap sempurna. Sentrifugasi pada 14-16.000 selama 30 detik untuk mengelusi DNA murni.

\section{Uji Hasil Isolasi DNA}

Kemurnian hasil isolasi genom DNA bakteri diuji dengan menggunakan alat nanodrop, langkah-langkahnya adalah sebai berikut: 
1. Blank Nanodrop menggunakan 5 mikrolit buffer TE.

2. Meneteskan 5 mikrolit sampel DNA pada Nanodrop.

3. Membaca grafik kemurnian dan konsentrasi DNA

\section{Amplifikasi gen smtAB}

Amplifikasi gen $\operatorname{smt} A B$ dilakukan dengan metode PCR dengan primer smt1 (5' GAT CGA CGT TGC AGA GAC AG 3') dan smt2 (5' GAT CGA GGG CGT TTT GAT AA 3'), denaturasi awal pada suhu $94^{\circ} \mathrm{C}$ selama 3 menit, denaturasi pada suhu $94^{\circ} \mathrm{C}$ selama 1 menit, annealing pada suhu $56^{\circ} \mathrm{C}$ selama 1 menit, Elongasi pada suhu $72^{\circ} \mathrm{C}$ selama 1 menit, pasca elongasi pada suhu $72^{\circ} \mathrm{C}$ selama 5 menit dilakukan sebanyak 35 siklus. Untuk mendeteksi apakah gen target telah diseparasi dilakukan elektroforesis. Proses elektroforesis menggunakan elektroforesis horizontal pada gel 1,5\%.Produk hasil berupa amplikon gen smt $\mathrm{AB}$ yang teramplifikasi melalui PCR dikirim ke perusahaan (First BASE, Laboratories Selangor, Malaysia) untuk disekuensing. Alat yang digunakan adalah ABI PRISM 3730 Genomic Analyzer, Biosystem USA

\section{Analisis Hasil Sekuensing}

Sekuens gen smtAB hasil sekuensing dianalisis menggunakan menggunakan program BLAST pada website www.ncbi.nlm.gov

\section{HASIL DAN PEMBAHASAN}

Isolasi genom DNA bakteri Bacillus alvei, Bacillus pumilus dan Bacillus lichenformis yang dilakukan menggunakan Presto mini gDNA Bacteria Kit memberikan hasil yang optimal. Berdasarkan Pengukuran konsentrasi DNA menggunakan spektrofotometer Nano Drop 2000 pada panjang gelombang 260/280 nm (Tabel 4.9) isolat $\mathrm{H}$ memiliki rasio $260 / 280 \mathrm{~nm}$ sebesar 1,857, isolat $\mathrm{E}$ memiliki rasio $260 / 280 \mathrm{~nm}$ sebesar 1,883 dan isolat $F$ memilik rasio 260/280 $\mathrm{nm}$ sebesar 1,877. Nilai rasio 260/280 $\mathrm{nm}$ tiap isolat tersebut menunjukkan bahwa ketiga isolat telah murni tanpa kontaminan apapun. Hal ini didukung oleh penyataan Clark (2005) bahwa DNA dinyatakan murni jika memiliki nilai rasio Optical Density (OD) 260/280 sebesar 1,8-1,9. Rasio ( $260 / \AA ̊ 280)$ kurang dari 1,8 menunjukkan kontaminasi fenol atau protein, sedangkan rasio lebih dari 1,9 menunjukkan kontaminasi RNA (Khosravinia et al., 2007) 
Tabel 1 Kemurnian Genom DNA Bakteri Indigen Paling Potensial

\begin{tabular}{ccc}
\hline Sampel & Rasio $\mathbf{\lambda 2 6 0 / \boldsymbol { \lambda 2 8 0 }}$ & Konsentrasi $\boldsymbol{\mu g} / \mathbf{g}$ sampel \\
\hline Bacillus alvei & 1,857 & 135 \\
Bacillus pumilus & 1,883 & 187 \\
Bacillus lichenformis & 1,877 & 101 \\
\hline
\end{tabular}

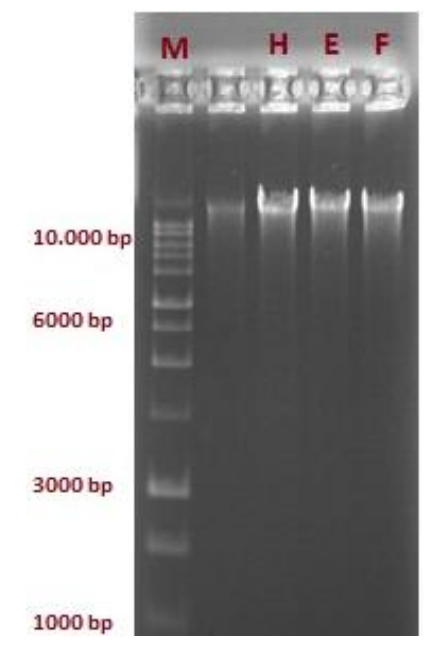

Gambar 1 Pola Elektroforesis DNA Genom

Bakteri Indigen

Keterangan: Marker $=1 \mathrm{~kb}, \mathrm{H}=$ Bacillus alvei, $E=$ Bacillus pumilus dan $\mathrm{F}=$ Bacillus lichenformis

Berdasarkan visualisasi (Gambar1) hasil elektroforesis genom DNA ketiga bakteri terdeteksi adanya molekul dengan diatas wilayah 10.000 bp. Ukuran pita yang jelas dan tebal mengindikasikan bahwa konsentrasi molekul yang terseparasi pada wilayah ini tinggi. Tertahannya laju migrasi molekul pada daerah 10000 bp mengindikasikan bahwa molekul tersebut adalah molekul DNA kromosom bakteri, karena berdasarkan penelitian Demerdash (2012) kromosom bakteri memiliki ukuran lebih dari 10000 bp, yakni 21000 bp - 23000 bp. Wang dalam Nuroniyah (2012) juga melaporkan bahwa pola pita elektroforesis DNA kromosom bakteri dengan menggunakan marka DNA 250bp-10000bp terpisah pada daerah diatas $10000 \mathrm{bp}$.

Amplifikasi gen target pada isolat bakteri indigen $\mathrm{H}$, $\mathrm{E}$ dan $\mathrm{F}$ telah dilakukan dengan menggunakan sepasang primer smtl (5' GAT CGA CGT TGC AGA GAC AG 3') dan smt2 (5' GAT CGA GGG CGT TTT GAT AA 3') dengan suhu denaturasi awal sebesar $94^{\circ} \mathrm{C}$ selama 3 menit, 1 menit denaturasi dengan suhu $94^{\circ} \mathrm{C}$, anealling selama 1 menit dengan suhu $56^{\circ} \mathrm{C}, 1$ menit elongasi dengan suhu $72^{\circ} \mathrm{C}$ dan 5 menit pasca elongasi dengan suhu $72^{\circ} \mathrm{C}$ sebanyak 35 siklus. Hanya isolat bakteri indigen $\mathrm{H}$ yang berhasil teramplifikasi dengan panjang sekuen gen berkisar 500bp. Amplifikasi gen target dengan panjang 500bp adalah sesuai dengan amplikon yang diharapkan dari sepasang primer yang telah digunakan sehingga hanya isolat bakteri indigen $\mathrm{H}$ yang akan disekuensing. Hasil amplifikasi fragmen gen smtAB disajikan dalam Gambar 2 


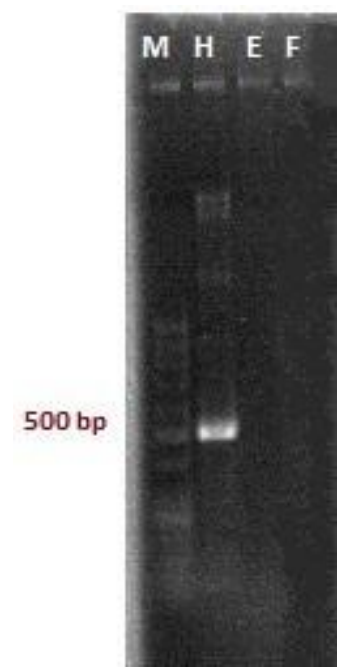

Gambar 2 Amplifikasi Daerah Gen Target

Keterangan: Marker $=1 \mathrm{~kb}, \mathrm{H}=$ Bacillus alvei, $E=$ Bacillus pumilus dan $\mathrm{F}=$ Bacillus lichenformis

Pengecekan hasil PCR yang dilakukan dengan elektroforesis menunjukkan band (pita DNA) pada isolat $\mathrm{H}$ sepanjang \pm 500 bp (Gambar 2) sedangkan untuk isolat $\mathrm{E}$ dan $\mathrm{F}$ tidak menunjukkan amplifikasi. Hal ini berarti pada isolat $\mathrm{H}$ terdapat gen $\operatorname{smt} A B$ sedangkan pada isolat $\mathrm{E}$ dan $\mathrm{F}$ tidak terdapat gen smtAB. Salah satu kemungkinan tidak teramplifikasinya sekuen gen $\operatorname{sm} t A B$. pada isolat bakteri $\mathrm{E}$

dan $\mathrm{F}$ adalah perbedaan sekuen gen pada isolat bakteri $\mathrm{E}$ dan $\mathrm{F}$ dengan primer yang digunakan. Yuwono (2006) menyebutkan bahwa pada saat proses annealing, primer akan menempel pada untaian DNA yang telah terpisah menjadi rantai tunggal. Primer tersebut selanjutnya akan membentuk ikatan hidrogen dengan untaian DNA pada daerah sekuen yang komplementer dengan sekuen primer. Berdasarkan hasil tersebut dapat dikatakan, isolat bakteri $\mathrm{E}$ dan $\mathrm{F}$ tidak memiliki sekuen yang komplementer dengan perekatan primer gen pengkode metallotionein.

Hasil analisis sekuen fragmen gen $\operatorname{smt} A B$ yang dilakukan menunjukkan panjang sekuens basa nukleotida adalah sebesar 479 bp. Sekuens nukleotida hasil sekuensing ditunjukkan pada Gambar 3
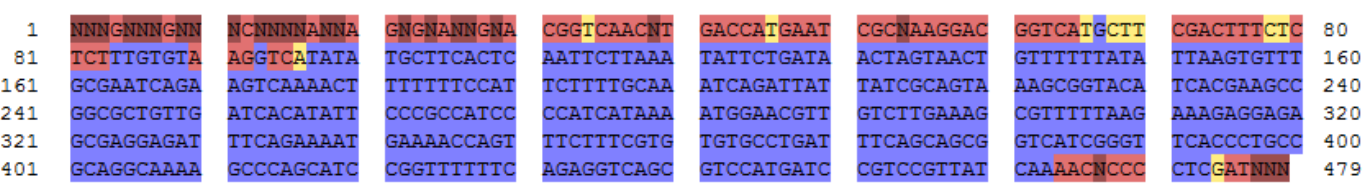

Gambar 3 Hasil sekuensing

Hasil amplifikasi yang diduga telah

Biosystem USA. Analisis data hasil mengamplifikasi gen target di baca urutan sekuensing menggunakan fasilitas Peak basanya menggunakan alat sekuenser ABI trace (online) dan BLAST Hasil PRISM 3730 Genomic Analyzer, sekuensing fragmen DNA menunjukkan 
panjang sekuens basa nukleotida adalah Trace untuk memaksimalkan pembacaan sebesar 479 bp yang diperoleh tidak peak (puncak-puncak kromatrogram). spesifik, terlihat dari adanya urutan basa Notasi $\mathrm{N}$ menunjukkan sekuens ganda yang tidak terbaca yang ditunjukkan pada bagian awal dan akhir fragmen dengan munculnya notasi N. Sekuen DNA (Gambar 4)

dikoreksi menggunakan aplikasi Peak

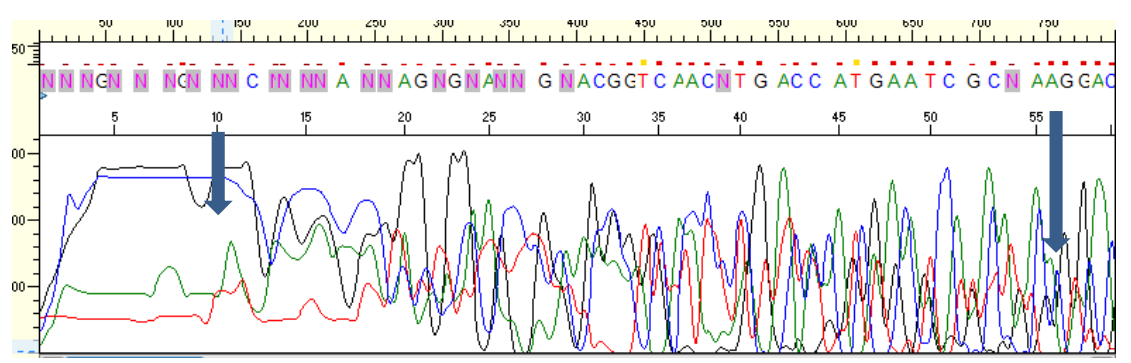

Gambar 4 Bagian dari Sekuen yang Terbaca 'N' Memiliki Peak Ganda (anak panah)

Fragmen yang teramplifikasi tidak menunjukkan sekuen yang spesifik ditunjukkan dengan banyaknya notasi $\mathrm{N}$. Urutan basa nukleotida dibaca oleh alat sekuensing berdasarkan peak (puncak grafik) kromatogram yang mencirikan suatu basa nukleotida, umumnya menggunakan pembeda warna. Sekuen tidak spesifik ditunjukkan oleh kromatogram dan karakterisasi hasil sekuensing dapat dilakukan berdasarkan kromatogram tersebut (McGill, 2012).

Query merupakan frekuensi basa nukleotida yang sama dengan sekuen gen referensi yang ditunjukkan dengan persentase kesamaan. Hasil analisis BLAST dari sekuen menunjukkan Query sebesar $80 \%$ dengan genom bakteri Bacillus amyloliquenfaciens L33. Hal tersebut menunjukkan bahwa sekuen yang didapat merupakan bagian dari genom bakteri tetapi bukan gen target yang diinginkan. Hal ini diduga disebabkan oleh kesalahan desain primer.Desain primer memegang peran penting untuk memastikan gen atau DNA yang teramplifikasi adalah spesifik atau tunggal (Thompson, 2006). Primer yang didesain tidak spesifik atau terlalu umum dijumpai urutannya disepanjang gen target menyebabkan munculnya lebih dari satu tapak perlekatan primer (binding side) (McGill, 2012). Hasil visualisasi fragmen hasil PCR (Gambar 2.) menunjukkan satu pita, sehingga kemungkinannya fragmen yang teramplifikasi bukan daerah conserve gen target melainkan bagain dari genom. Daerah conserve merupakan 
bagian urutan gen yang memiliki susunan basa yang konstan pada sekelompok makluk hidup sehingga dapat dijadikan pengenal gen target (Tang et al., 2012). Hasil penelitian ini diketahui bahwa pendesainan primer pada daerah conserve dari spesies yang berbeda memberikan kemungkinan untuk terjadi amplifikasi ganda yang menyebabkan kesulitan dalam identifikasi gen target. Primer yang didesain sebaiknya dapat mengamplifikasi secara spesifik lokus gen target. Referensi sekuen gen yang berasal dari kerabat yang tidak dekat perlu dikaji dari sudut pandang lain yaitu diantaranya posisi translasi yang benar (Open Reading Frame atau ORF), ekson-intron (Thomas et al., 2006), serta homologi evolusioner (Thompson dan Denis, 2006). Hal lain yang harus diperhatikan dalam merancang primer adalah bahwa gen yang mengkode sifat tertentu pada beberapa jenis makhluk hidup umumnya memiliki kesamaan namun bersifat spesifik baik dalam hal urutan basa nukleotida maupun urutan asam amino (Thomas et al., 2006).

\section{Kesimpulan dan Saran}

Berdasarkan hasil penelitian ini dapat dikemukakan kesimpulan sebagai beikut spesies bakteri indigen dari limbah cair agar PT X yang memiliki gen $\operatorname{smt} A B$ adalah bacillus alvei. isolasi gen $\operatorname{smt} A B$ menghasilkan sekuen yang tidak spesifik dengan gen target.

Saran untuk penelitian selanjutnya adalah perlu adanya penggunaan primer yang lebih spesifik dan metode isolasi yang berbeda dengan penelitian ini.

\section{DAFTAR PUSTAKA}

Buhani.2007.Alga Sebagai Biondikator dan Biosorben Logam Berat Bagian :1". tersedia di: http//www.chemistry.org diakses pada 10 januari 2015

Clark, D. 2005. Molecular Biology. USA: Elsevier Academic Press.

Fonte, R., Agosti, A., Scafa, F and Chandura, S.M. Anemia and Abdiminal Pain Due to Occupational Lead Poisoning. Haematologica. 2007. 92: 13-14

Gerdhart, K.E., Huang, X.., Bernard R., Greenberg., and Bruce, M. 2008. Phytoremediation of organic soil contaminants: potential and challenges. Journal of Phytoremediation. Department of Biology University of Waterloo. Elsevier Science Limited.Canada.

Khasanah, Eliya.2009. Adsorpsi Logam Berat. Oceana. Vol XXXIV No $4: 1-7$

Khosravinia, H., H. N. N. Murthy, D. T. Prasad, \& N. Pirany. 2007. Optimizing Factors Influencing DNA extraction. African Journal of Biotechnology, 6(4). 481-486

Knox, A.S., Seaman, J., Andriano, D.C., dan Pierzynski, G. 2000. 
Chemostabilization of metals in contaminated soils:

Bioremediation of Cotaminated Soils. New York: Marcek Dekker Inc. hlm 811-836.

Lam, T.V., Agovino, P., Niu, X. And Roche, L., Linkage Study of Cancer Risk Among Lead Exposed Worker in New Jersy. Sci Total Environ. 2007. 372:455-462.

McGill. 2012. Trubleshooting Sequencing Product. McGill University and Genome Quebec innovation Centre Sequencing Servise

Nuroniyah dan Putra 2012. Identifikasi Spesies Isolat Bakteri S1 Dengan Metode Analisa Sekuen Fragmen Gen 16S rDNA. Jurnal Teknik Pomits Vol. 1, No. 1, (2012) 1-6

Soleimani, Mohsen and Jaberi, Najmeh. 2014. Comparison of Biological and Thermal Remediation Methods in Decontamination of Oil Plluted Soils. J. Bioremed Biodeg. 5: 3.

Shimoda, Ryuya., Achanzar, William E., Qu., Wei., Nagamine, Takeaki., And Takagi, Hitoshi. 2003. Metallothionein is a Potential Negative Regulator of Apoptosis. Toxicological Science. Vol. 73: $294-300$

Suhendrayatna, 2001, Bioremoval Logam Berat Dengan Menggunakan Microorganime (Suatu Kajian Pustaka). Makalah Disampaikan pada Seminar on-air Bioteknologi Untuk Indonesia, 1-4 Februari

Steenland, K and Boffeta, P. Lead and Cancer in Humans: Where We Are Now?. J. Ind.Med.. 2000. 38:295299
Tang, L., Gao, H., Zhu, X., Wang, X., Zhou, M., Jiang, R. 2012. Construction Small Intelligent Focused Mutagenic Libraries Using Well Designed Combination Degenerate Primers. BioTechniques 149-158

Thomas, P.J., Anand, T., Suresh, P., Janarthnan., S., Vincent. 2006. Designing Specific Oligonukleotide Primers for Metallothionein Genes. Indian Journal of Biotechnology vol. 5, pp.120-122

Thompson, B., Denis. 2006. Finding Homologous Genes With Primers Designed Using Evolutionary Models (Dissertation). North Caroline State University

Yuwono,T. 2006. Teori dan Aplikasi Polymerase Chain Reaction (PCR). Andi. Yogyakarta. 231 hal.

Zulaika, E., 2012. Bakteri Resisten Logam Berat Yang Berpotensi Sebagai Biosorben Dan Bioakumulator.Disampaikan pada Seminar Nasional Waste Managament For Suistainable Urban Developing Teknik Lingkungan ITS, 21 Februari 2012 